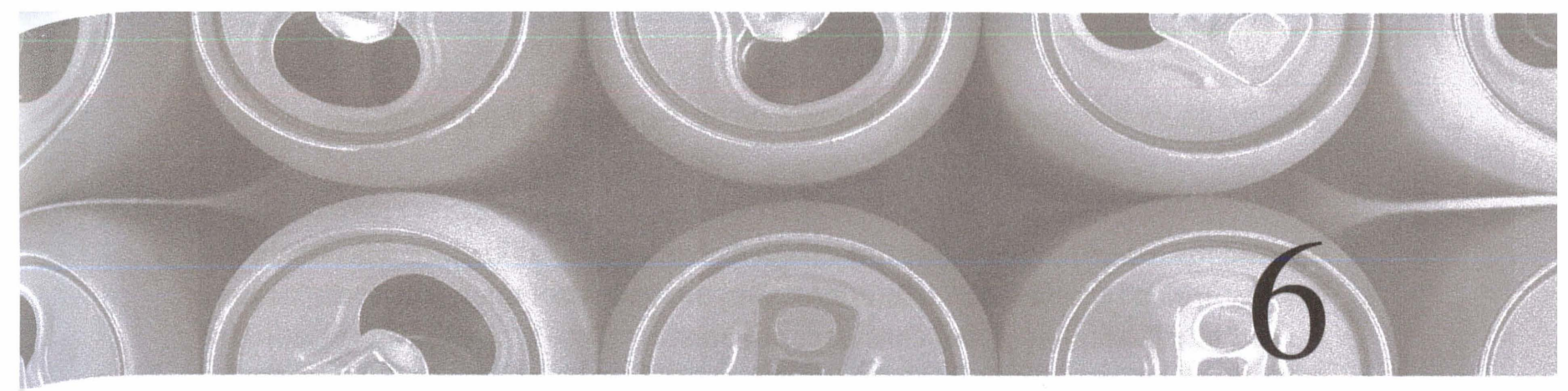

\title{
Debunking the Myths of Global Consumer Culture Literature
}

\author{
Güliz Ger, Eminegül Karababa, Alev Kuruoğlu, \\ Meltem Türe, Tuba Üstüner and Baskin Yenicioğlu
}

\section{INTRODUCTION}

Globalization and global markets are typically considered in terms of production and supply chains across the world. However, globalization and its specific local encounters transform and are transformed by the consumption of goods and imaginaries as profoundly as production. Global capitalism may well be driven more significantly by new forms of consumption than by production (Comaroff and Comaroff 2005; Friedman 2005). Hence, consumption studies and marketing/consumer research have a lot to contribute to the understanding of globalization and global markets. However, cross-fertilization among disciplines has usually been scarce (see Richard Wilk's work for an exception) - for example, between anthropology and economics and political economy, between consumption studies and marketing/consumer research, or between micro and macro perspectives. Analyses of global capitalism and consumption, or neoliberal markets and consumer behavior have typically been conducted within disciplinary and sub-disciplinary boundaries. For example, macro-processes of accumulation in the world economy are more often analyzed by political scientists and economists whereas consumption patterns and consumer behavior are studied by marketing/consumption researchers, and the challenges globalization poses, such as rising inequality or ethnic violence are explored by anthropologists and sociologists. Contrary to the disciplinary focus in academia, Robertson and White (2005) point to the multidimensionality of global phenomenon in the real world: each and every phenomenon have cultural, social, political, and economic aspects. Thus, they argue that 'globalization is a site upon which relationships between disciplines are being restructured' (p. 347). The embeddedness of these multiple dimensions make it even more difficult to explain global markets and consumption with the compartmentalized approach in disciplines and sub-disciplines. Interrogating the grip of disciplinary 
(and micro-macro) boundaries, this chapter reviews several key domains of the literature critically, revealing assumptions, myths and ideologies that seem to have shaped scholarship on global consumer cultures.

The earliest theses about global consumption can be grouped into two opposing camps, with one group defining globalization as a process of emulation, while the other arguing that it is a process of resistance. Each camp had their respective predictions of global outcomes. While the former camp predicted that the end of globalization will be global homogenization, the latter one suggested that it will be heterogenization (Featherstone 1990; Ger 2017; Wilk 1995, 1998). Criticisms and debates on these views yielded diverse arguments. Over time these arguments converged on the highly influential accounts of hybridity and global flows (Appadurai 1990; Burke 2009; Hannerz 1987, 1992, 1996; Pieterse 2001 and 2009). Currently, from a sociocultural perspective (Tomlinson 1999), globalization is regarded in terms of 'complex connectivity' that widens, deepens and accelerates the social interactions across the planet. There are particular flows that make this connectivity possible. Appadurai (1990) defines these flows as mediascapes, finanscapes, ideoscapes, ethnoscapes and technoscapes. These flows facilitate the formation of particular hybrid consumption patterns and objects (Ger and Belk 1996). Moreover, globalization entails extensive reflexive global consciousness (Beck 2000; Tomlinson 1999). Accordingly, social processes and ways of life, including consumption and market relations, come to entail local manifestations of global patterns, representing 'glocalization' or 'sameness-within-difference' (Robertson 1995; Robertson and White 2005) and 'structures of common difference' (Wilk 1995, 2010). Such complex connectivity 'in one form or another is impacting on the lives of everyone on the planet' (Beynon and Dunkerley 2000, p. 3).

Given that global consumer culture is now a critical force in everyone's lives, it is important that we understand what it is and how it impacts us. One way to go about doing this could have been to revisit and summarize all that has been said on globalization so far (see Ger 2017 for such a review). This chapter is not going to take this path. Rather, our focus is on what is 'unsaid'. We will identify and debunk and/or question the taken-for-granted assumptions about and myths of the global consumer culture literature.

The first step towards this goal is to remind ourselves that we as academics are not outside of the grips of ideologies that surround our work. Ideologies shape individuals' belief systems and assumptions and consumers are not always reflexive of the impact of ideology (Wilk 2006 a,b,c). Interestingly, much like the consumers, we, the researchers, sometimes fall for the very same pitfalls. We do not always give due attention to what ideologies are being manifested in the concepts we use in our work. We are not always aware of how they might be shaping our thinking as scholars.

Following, we question and expose some of the myths, narratives, ideologies and assumptions researchers take for granted when they discuss and study consumption in a global world. First, we take issue with the myth that globalization is a recent condition. We argue that globalization is not a condition but a process and it is neither recent nor linear. It is shaped by historical socio-cultural and economic forces with different powerful centers shaping the process at each era. Next, we question the extent to which the encounter of the local cultures with the foreign is playful. We draw 
attention to the inequalities at play in hybridization and its valorization - the colonial gaze and the status games inherent in consumption of cultural differences, which can re-enforce rather than eradicate boundaries. Then, we take issue with one of the most important flows of globalization: immigration. We argue that immigrant consumption is not only about acculturation. We debunk the ideologies that structure our findings within the acculturation literature and argue that a more nuanced and critical understanding of immigrant consumption requires seeing immigrants as people, focusing on their different life worlds as opposed to lumping all same country of origin people together as one group such as Mexican Americans or British Pakistanis. Next, we deliberate how researchers approach morality and belief in the less privileged/nonWestern context in comparison to the dominant/Western contexts. We contend that scholars operate with theoretical and methodological blinders which (un)intentionally reify the dualisms (e.g., us/others, West/rest) that reinforce cultural boundaries by highlighting some beliefs/moralities as superior to and less extreme than others. Finally, we interrogate to what extent the age of digitally networked technologies emancipate the complex connectivities of globalization from the powerful grip of market structures. We underscore the architecture of the digital panopticon and the underlying market realities which can still turn participatory moments into commodities for the profit of a few.

\section{DEBUNKING THE MYTH THAT GLOBALIZATION IS A RECENT CONDITION}

Scholars influential in consumption studies (e.g., Giddens 1990; Levitt 1983; Ritzer 1996) have placed globalization as a novel condition specific to the late twentieth century - as global markets, standardized products, or global orders of labor, production, governance, and military. This global condition is defined as transnational integration within which people are connected with a shared economic and cultural network of relationships, shaped by a globally shared consciousness. On the other hand, historians note the presence of global interactions from antiquity onwards and thus argue that globalization is a process and not a condition (Armitage 2004; Featherstone 1990; Hopkins 2002; Stearns 2010). Rather than arguing for or against the existence of such a condition at a specific time, historians argue that we should scrutinize globalization as a process, explaining the transformation of local into global via interactions among societies through migration, trades, diseases, wars and conquests. That is, contingencies and the processes of local societies converge in cultural, institutional, structural and psychological terms (Eisenstadt and Schluchter 1998; Stearns 2010). Research in consumer culture often focuses on current globalization processes - such as glocalization, hybridization, acculturation, and formation processes of global consumer subjectivities and consumer cultures - under conditions such as neoliberal economic order, intense migration, globally diffused digital technologies, and shifting global economic centers. However, there are two main advantages of debunking this myth of the recency of globalization and having a historical perspective. 
The first advantage is to see how past patterns of global interactions form the present global markets and consumer cultures (Kjeldgaard and Ostberg 2007; Pieterse 2009; Wilk 2006c). The second advantage is to build novel understandings of how interregional or global interactions co-constitute past markets and consumer cultures in different geographies (Karababa 2015; Karababa and Ger 2011). Such a perspective will help identify the formation processes of global markets and consumer cultures under different contexts far from contemporary milieu and provide a deeper conceptualization of global formations of markets and consumer cultures.

Foundations of globalization go back as early as 3000 BCE when agriculture, urban markets, migrations and trade grew (Hopkins 2002; Stearns 2010; Pieterse 2012). Migration and trade were two important interactions - taking different shapes in different eras - between societies operating for thousands of years. The migrations in $1000 \mathrm{BCE}$ resulted in a one-way interaction: immigrants who went to very far lands rarely returned to their former homes. In this period, the localism of previous ages was slowly disappearing. Connections among different regions were becoming possible through, for example, land and sea trade in the Persian Gulf and India or the exchange of precious stones and flint among east European societies.

After 1000 BCE, the emergent empires in Asia, Europe and the Middle East secured trade routes (Stearns 2010). As a result, the Silk Road and the Spice route circulated commodities across far lands. Treasured commodities such as silk from China were sold to the upper classes of the Roman Empire or the elites of Persia, the Middle East, or India. The Chinese silk changed the tastes of the upper classes and created a craze in the upper echelons of the Roman Empire, if not among the ordinary people. However, there were no such Western goods that captured the fantasy of the Chinese elite. Yet, during the period, value systems, arts, religions and social institutions did not accompany the material flows (Pieterse 2012; Stearn 2010). We have to note that for a long while, the West was not the dominant center of flows, it was located at the periphery, on the receiving side. Looking back into the history of commodity chains reveals multiple shifts in the center-periphery relations throughout time. Especially worthy of study are the shifts in the production, marketing and consumption practices along the global commodity chains, reflecting the power relations between different regions and their influence on the formation of global markets (Dicken 2007).

By $1000 \mathrm{CE}$, interregional convergence started to blossom, giving pace to the formation of an interregional consumer culture. Adventurers, missionaries and merchants were actors of global processes, traveling to the far lands. The 'seven wonders of the world' had been created and the curious traveled to far lands founding ancient tourism (Stearns 2010). Most of the recorded travel was from the west to the east. After $1000 \mathrm{CE}$, consumers in the west were interested in exotic goods, medicinal herbs and precious goods from the east (Stearns 2010). Indian calico, china, sugar, silver items, mirrors were some of the goods traveling between regions of Asia, Africa, the Middle East and Europe. During this period, Arab merchants were active in interregional trade, linking the Middle East with the Indian Ocean. Arabic became the lingua franca of the Indian Ocean.

In the sixteenth century, the new technologies and resulting discoveries of the new lands expanded the scope of the interregional trade. Mobile diasporic networks, as a specific social and economic formation also created connections between the cities 
sprouting on the trade routes (Hopkins 2002). Consumption depended on international trade and developed extensively in China and the Middle East (Stearns 2006). Eurasian realms like the Spanish, Ottoman, Chinese and Safavid empires experienced consumer cultures where commodities including the exotic and luxurious were spreading beyond the elites, and fashion and leisure were commercialized (Clunas 2004; Karababa 2012; Karababa and Ger 2011; Minowa and Witkowski 2009). Also a consumer subject interested in nature, science and aesthetics was forming in different parts of the Mediterranean (Febvre 1977; Karababa 2015).

Later during the eighteenth century, colonialism introduced new ways of interaction. Procedures installed by religion, law, education, labor and military service in the colonized regions were used to transform the 'undesirable' qualities of the local into 'desirable' ones (Canniford and Karababa 2013). As a practice of imperial globalization (Hopkins 2002), colonization engendered the exchange of people, goods, ideas and technologies, which were transferred from one colony to another. International companies like the East India Company, missionaries and migrants were other actors who had a catalytic effect in the interaction between the colonizers and the colonized. While imperial order was introduced to the colonies, new belief systems, tastes, practices, products, languages, the local and the global started to enmesh. Today's glocalization may well date back to this period. The strong asymmetry of power between the colonizer and the colonized defined the nature of interaction and highlighted the separation between the colonial West and the local other.

The nineteenth century's modern nation state, industrial revolution, integrated communication systems and liberal ideology positioned the West as a dominant power, the center and the locomotive of globalization (Giddens 1990; Hopkins 2002). Mass production imposed standardization rather than difference, which used to be an important precondition of trade (Hopkins 2002). The characteristics of Western society began to diffuse to the globe.

These early forms of interactions were shaped under conditions changing from milieu to milieu such as changes in the density and direction of migration, technologies of transportation, production and communication, government institutions, economic institutions, religious and moral discourses, and trade networks. Globalization has been a process where the relative dominance of actors from the East and the West, of peoples from different societies has been shifting over time.

In addition, like today, history witnesses globalization as a cyclical and reversible process (James 2009). Previous incidences of globalizations came to an end as a result of wars, financial crises and globalization of violence, where at times people move away from global settings to more secure places (James 2009). Therefore, we need to challenge the myths of globalization as a condition as well as a linear progression.

\section{'EATING THE OTHER': QUESTIONING THE MYTH OF PLAYFUL ENCOUNTERS OF THE LOCAL AND THE GLOBAL}

Globalization is often linked to hybridity. This is a world "where reggae emerges from the slums of Kingston, and mixes with hundreds of other local musical styles, 
in a kind of creative ferment that leads to Australian Aboriginal reggae played with a didgeridoo and Japanese Rastafarians winning Jamaican DJ competitions' (Wilk 2006a: 6-7). Local cultures have absorbed and appropriated outside influences into ways that 'fit' their own histories (Wilk 2006a).

Such an account, at first glance, suggests a playful encounter of 'local' cultures with global flows, wherein 'new meanings and modes of expressing them can be born', and 'foreign cultural influences need not involve only an impoverishment of local and national culture' (Hannerz 1987: 555) - but rather may give people new means of managing and representing 'their own culture' (Ger 1999). Moreover, hybridization has long taken place, in nature and among cultures (Pieterse 2001). Critics have argued that hybridity is a 'plaything of the elite', yet Pieterse notes that it is in fact the lower-classes that mix and match the most - exemplifying such cases as rap by Turkish minorities in Germany. While the mimicry of colonizers can be a reproduction of their hegemony; hybridity can also destabilize - what Bhabha calls 'sly civility' - through such interventions (1985a, 1985b) as irony or civil disobedience. Yet, hybridity that is consumed through (mainstream) market/spaces does not necessarily indicate or lead to an eradication of the divide across classes, or ethnic/religious/gender identities within or across national borders. Rather, as Pieterse notes, the contingency of boundaries is more common than ever.

The fact that some (and not all) melanges stand out as 'hybrids' is indicative of inequality at play: selection of what becomes mixed and matched and what is valorized as such. A particular 'global gaze' is influential in choosing what becomes the object of preservation/cross-pollination/(re)presentation. Critical perspectives on hybridity and global flows argue that more often than not, the very process of 'hybridizing' itself is not only an affirmation of boundaries but also serves the verifying dominance of the 'mainstream' - as in an imagined 'Western' - order. The 'obsession' with boundaries (Pieterse 2001), on behalf of the 'West' as well as the 'rest' is what is problematic.

These boundaries are intimately linked to (a historical development of) inequality within as well as amongst locales and cultures. Shohat has argued, 'A celebration of syncretism and hybridity per se, if not articulated in conjunction with questions of hegemony and neo-colonial power relations, runs the risk of appearing to sanctify the fait accompli of colonial violence' (1992: 109). Ahmed (2000) cautions that the conditions of the meeting and mixing of the two are not equal. Rather, the 'other' is transformed in a way that (re)produces and commodifies the divide between the 'us' and the 'stranger'. With this transformation, the stranger is now familiarized and thus no longer someone to be feared, but rather someone whose difference needs to be celebrated. The white-dominant subject, argues bells hooks, relates to the body and practices of the non-mainstream 'Other' as 'an alternative playground where members of dominating races, genders, sexual practices affirm their power-over in intimate relations with the Other' (hooks 1992: 23). Root (1996) deems such consumption of cultural differences as 'cannibalistic' and Heldke (2001) has termed practices of culinary adventurousness as 'food colonialism' - an act of 'consuming' the other without necessarily showing any interest in or concern for the origins of the food; as well as the 'selection' process whereby certain foods are chosen, exoticized and commodified. Heldke notes, moreover, that the process of writing cookbooks may reproduce colonial hegemonies: recipes are gathered without crediting the work 
of the locals that goes into the preparation process; and foods that did not exist in the 'local' setting may be 'fabricated' (Narayan 1995).

The 'Other', in its edible and palatable form, serves as an essentialized mystical and emotional resource for the West, which in modernity has been deprived of its 'authenticity.' Importantly, this is also the perspective through which those who were colonized/exoticized came to understand themselves (Cook and Harrison 2003; see also Fanon 1967; Said 1978). Difference and strangeness, thus, are not necessarily constitutive of resistance against the global and colonial forces and flows, but rather are commodified (Grossberg 1995; Turgeon and Pastinelli 2002) and inverted, by the Others towards themselves.

Wilk (1995, 2006a) has conceptualized that this (co)construction and commodification of that difference is common throughout the world, in a way that he terms 'replication of diversity' (Wilk 1995: 118). Local dramas are played out in the global stage, through what Wilk terms 'structures of common difference'. In other words, 'cultures become different in uniform ways' (Wilk 1995: 118). Such process is not divorced from colonialism - the (formerly) colonized have become complicit in their self-production as commodities. This points us towards another important process: the process whereby those in the third world/less affluent world/'East' cast the Western/imperialist gaze upon themselves and (re)present and (re)imagine their (non-mainstream) bodies, cultures, practices as consumable resources or as open to becoming consumed and/or 'hybridized' by 'Western' influence.

Beauty is one field in which the colonial gaze is both projected upon and internalized by subjects. Mears (2010), in her ethnography on the world of high-fashion modelling, draws attention to the 'imperial gaze' on women, and notes how 'darker' bodies, when employed by the fashion industry at all, are 'posed and styled in exotic juxtaposition to the normatively white female body' (Mears 2010: 24). Wilk (1995), in his account of beauty contests in Belize, indicates that Belizean pageant contestants partially conform to local ideals of beauty, but also notes that 'an intimate awareness of the global gaze' (p. 127) shapes the way that the pageant plays out, and the way that beauty is defined and judged.

Another Belizean example is that of 'authentic' Belizean food: an invention literally 'cooked up' by Belizeans and foreign entrepreneurs, primarily to serve to tourists (Wilk 2006a). The Belizean local 'culture' has not only become commodified - it has been constructed and produced as 'local' in the first place. Certain elements of 'culture' get selected, invented and appropriated for production, preservation and consumption, be it by the 'foreigners' who are looking to find the exotic-authentic or by the locals who are trying to cultivate such experiences for tourists/outsiders, or even for themselves. Difference becomes a matter of 'style' within consumer culture in a way that occludes (past and present) antagonisms and violence (Ahmed 2000).

The consumption of the 'Other' - i.e., both the consumption of 'Western' products by the less developed world, and the consumption of the exotic East by the West can serve similar purposes: status and display of capital. In the context of the 'East', the West is consumed as an indicator of having attained a 'normal', modern and middle-class status (e.g., Kravets and Sandikci 2014; Liechty 2002). In the 'West,' the exotic other affords avenues of displaying cultural capital through knowledge and appreciation of other cultures. In both cases, there is a display (and also a building) 
of cultural capital involved: people learn how to mix and match, how to arrange and organize (e.g., Holt 1998; Üstüner and Holt 2010). But in effect, these objects of consumption serve to produce and consolidate differences and boundaries (while sometimes offering the illusion that boundaries are crossed.) Ahmed (2000) argues that 'this perception of objects as having difference is itself an effect of the very processes of production and exchange embedded in consumer culture' (Ahmed 2000: 116). Accessing these differences or 'exotic' objects and controlling their circulation (Altglas 2014) is often a means through which the affluent build upon their status being 'cosmopolitan', and knowing how/what to consume in terms of the exotic in the developed world is now a source of prestige.

Discussions on cosmopolitanism also tie into issues of mainstreamness-otherness and the constitution of the nation as an imagined community. Cosmopolitanism, as a political commitment, entails an openness to diversity and the possibility of being changed by encounters with the Others (Skrbiš and Woodward 2013). Yet, Ahmed notes that while cosmopolitanism/multiculturalism discourse on the one hand is about incorporating 'strangers' (migrants, minorities, etc.) into the nation - the us/we it also serves as a reminder that 'we' have to live with 'them', thus reproducing the boundaries. She argues that multiculturalism also involves 'fetishizing' the stranger and her/his strangeness. This also relates to Said's conceptualization of Orientalism, that 'Europe' is produced through Orientalist discourse - the very notion that the Orient is what Europe is not. The us/we is similarly produced through this 'differentiation of familiar and strange' (Ahmed 2000: 97).

Through this critical lens, we question the playfulness that is attributed to consuming 'other' cultures - the myth of hybridity can easily occlude the colonial gaze that is inherent in seemingly innocent 'adventures' such as consuming 'food from other cultures' or appreciating 'the bridging of the East and the West' in music, arts and literature. While hybridity can indeed lead to economic benefits for some, what we as researchers need to remember, is how the colonizer's gaze continues to shape the way the 'non-West' perceives, (re)presents, produces, and consumes itself. To detect this gaze, then, is also to reveal inequality and dominance, as it plays out in the world scene - sometimes in contexts as seemingly innocent as food.

\section{DEBUNKING THE MYTH THAT IMMIGRANT CONSUMPTION IS ALL ABOUT ACCULTURATION}

Immigration is one of the most important forces of globalization. Today over 243 million people are living in a country different than their country of origin (United Nations Population Division). What is critical, at least for globalization scholars, is the extent of increase in immigration. The number of people who are starting a new life in a country different than their country of origin has been growing at an increasing rate. This increase is not only a manifestation of the expanding world population. Yes, there are more people living in the world in the 2010s compared to the 1800s; but more importantly, as a percentage, immigration is increasing even faster than the increase in world population. In 1995 immigrants made up $2.8 \%$ of the world's 
population. In 2005 they were $2.95 \%$ and in 2015 they were $3.3 \%$ of the world's population. All the political, economic and social indicators suggest that this trend will continue in the coming years. There will be more people living in a country different than their country of origin.

Given this trend, sociologists and marketing scholars have investigated immigration as an important social phenomenon. But the two literatures' foci have been diametrically opposite. On the one hand, the sociology of immigration literature is mostly interested in immigrants' and their children's educational and economic advancement trajectory (see Portes and Zhou 1993 for a quick review and introduction of the theory of segmented assimilation), and the structural drivers of xenophobia (Bohman 2015; Jaime-Castillo et al. 2016; Mierina and Koroleva 2015).

Marketing scholars' focus, on the other hand, have been mostly on uncovering how immigrants' consumption choices manifest and are manifested by the acculturation processes. So marketing scholars were able to engage with the topic of immigration from the perspective of immigrants' lived experiences, a perspective which is mostly lacking within the sociology literature.

However, as opposed to using a sociological lens to study immigrants' experiences, marketing scholars have mostly borrowed from the psychology literature. Almost all marketing studies on immigration engage with, what they call, the 'acculturation theory'. Acculturation theory was first developed within the psychology literature by Berry (1980). Its goal was to uncover immigrants' attitudes towards their host countries and categorize potential acculturation outcomes. Berry and colleagues uncovered four such outcomes: assimilation, separation, integration and marginalization. This theory was later adapted by Consumer Culture Theorists (Arnould and Thompson 2005) to understand immigrant consumer acculturation. Immigrant consumer acculturation is defined as 'the general process of movement and adaptation to the consumer culture environment in one country by persons from another country' (Peñaloza 1994: 33). Over the last two decades much valuable work has been conducted and published within the consumer acculturation literature. Due to space limitations, it is impossible to summarize those studies here with due diligence. But it is important to note that thanks to the consumer acculturation literature our understanding of immigrants' and host country citizens' consumer experiences is growing. We have moved away from the universalistic framework offered by Berry. We now know that acculturation is not an attitude-outcome. It is a process. There are antecedents and outcomes to this process. It is shaped by various socio-cultural structures and conditions. Outcomes are not solid. Neither do they fall in particular universalistic categories. Immigrants move between various possible identity positions.

Having said that, the accumulated work on immigrant consumers has very much been ideologically shaped by the acculturation theory's framework; limiting the marketing scholars' ability to develop a critical perspective. A simple etymology of the term acculturation reveals that the very early uses of the term indeed manifests a colonial ideology. According to the Oxford English Dictionary the word originated in the US around 1800s. The first use of the term surfaced in 1880 in the journal Introduction to the Study of the Indian Languages. Here acculturation is defined as a 'civilizing' force of the West: 'The force of acculturation under the overwhelming presence of millions of civilized people', by which the authors imply the Western 
colonialists 'wrought great changes'. Next it was used in Popular Science Monthly in 1888: 'We consider it a mistake to believe that an acculturation to our civilized ways is a thorough civilization'. Here the author implies that it is not enough to 'acculturate to the' West's 'civilized' ways. One can acculturate. But this does not mean that one will be civilized. Only people from the West are truly civilized. Interestingly this is a view still shared by some in the West in response to the refugee crisis in Europe. The next case is found in the Journal of Negro History in 1938: 'The overwhelming importance of the institution of slavery as the predeterminating factor in the influence and acculturation of the Negro ...'. This quote does not really need much explanation in our view in terms of what the author implies by acculturation.

Very much reflective of the early uses of the term, the Oxford English Dictionary defines acculturation as 'adoption of or adaptation to a different culture, especially that of a colonizing, conquering, or majority group' (our emphasis). There are two critical assumptions hidden in this definition.

First, it assumes that acculturation means adoption or adaptation. Consumer culture researchers have been much aware of the first assumption. Indeed, the second wave of acculturation studies is named post-assimilationist to highlight its break away from the first wave of studies which focuss on 'how much' as opposed to 'how' immigrants acculturate (Luedicke 2011). These studies acknowledge that adoption is not the only outcome. Indeed, many studies argue that rejection, or pendulism (Askegaard, Arnould and Kjeldgaard 2005), or hybrid identities (Oswald 1999) are potential acculturation outcomes. But interestingly, all marketing studies which focus on immigration start with the question of how immigrant consumers acculturate to their new host countries. Even though the studies acknowledge rejection, they treat it as only a negative case. Rejection is never the sole focus.

Neither do marketing scholars study immigrants as people, rather they study them as consumers. One could argue that they are consumer researchers so it makes sense that they focus on consumers. But if the marketing scholars could think of immigrants as people, they would then start seeing sociological differences between them. Immigrants might be from the same country of origin, but they might not belong to the same social class. They might not be endowed with the same level or extent of cultural capital. They might not have the same religion. They might not even have the same race. What if social class, religion or race is the driving factor behind immigrants' rejection of (or their feelings of being rejected by) their host country cultures. Üstüner and Holt (2007) claims that social class (economic, cultural and social capital) indeed makes a difference in acculturation outcomes; but much like other studies, they focus on how migrants acculturate and treat the 'shattered identity project' of two young second-generation squatter women in Turkey merely as a negative case. As a result, with the exception of those two Turkish women, most of the respondents in marketing studies are playful and ironic, seamlessly moving from one identity position to another. But then, when one reads about what has been happening in Europe recently, one starts wondering why the second-generation immigrants in the Parisian banlieue or the Belgian suburbs do not playfully oscillate between various identity positions.

The second assumption hidden within the definition of acculturation is that it involves a clash between two cultures, with the powerful, colonizing, conquering culture winning over the powerless, colonized and conquered one. In consumer culture 
literature the scholars acknowledge that there could be a cultural conflict between the host and home cultures. They study conflict (Luedicke 2015). But when they do, they assume that it is a clash between equal but different cultures. In doing so, they miss the power dynamics that are in play between the immigrant-receiving West and the immigrant-sending East. For example, Askegaard, Arnould and Kjeldgaard (2005) do not engage with colonial theory even when they are studying colonized immigrants (Greenlanders) in a colonizing host country (Denmark). In the tables they bury the colonial history under boxes titled 'discursive elements from the home culture', 'discursive elements from the host culture'. When scholars study conflict they study it using ahistorical, universalistic models which focus on the issues surrounding the 'interpretation and coordination' of relationships between immigrants and indigenes, as opposed to underlying historical factors that shape those interpretations (for example, see Luedicke's (2015) work on conflict between Turkish immigrants and Austrian indigenes).

If the marketing scholars were to strip themselves from these assumptions, they would have more to contribute to our general understanding of immigration and the immigrant experience. Their research would be more historical, cultural and sociological. They would no longer allow the research to take shape under the burdens of the psychology literature on immigrants' attitudes (Berry 1980, learning theory and the literature on assimilation. They would reject the use of universalistic relationship models (such as that of Fiske's) in explaining conflict. They would be able to break away from the ideology that has been shaping their work. Only then could they develop a more critical approach that represents and explains what is going on in the Parisian banlieues and the Belgian suburbs.

If marketing scholars could see immigrants as people and not only as consumers, they would be able to understand their experiences better. They would start seeing differences amongst the same country of origin people. They would distinguish between their different backgrounds and upbringings. They would uncover the different forces that brought immigrants to their host countries in the first place. They would then understand how those differences shape immigrants' lives and the ways in which they use consumption goods and experiences to negotiate their lives and expectations in their host countries.

\section{DEBUNKING THE MYTH OF THE MORAL 'US' AND RELIGIOUS 'OTHERS'}

Across the world, we are witnessing the reinforcement of boundaries and enunciation of difference in increasingly common ways (Pieterse 2001; Wilk 1995): a global political scene promoting division against connection (e.g., increasing support for conservative/nationalist politicians), seeming disintegration of global entities (e.g., the 'doom' of the EU, recent debates about the functionality of UN), and fear on a global scale triggered by world-wide terror attacks and waves of immigrants. Belief, as moral principles and religious orientation, has come to be used to normalize such divisions and deal with the fear of 'the other.' The ideologies and myths surrounding belief can polarize the world by constructing some moralities as superior to and 
less dangerous than others. And while, as social scientists, we have celebrated the hybridity of local/global belief systems, morality and religion, it is unlikely that our research is devoid of such constructions. Reflecting on the myths on which we build our research is crucial to reveal how we come to celebrate some moralities and scrutinize others and, hence, contribute to divisions and dualisms that we want to demolish.

Consumer research provides rich insights into how global culture manifests itself in moral consumption practices. Consumption blurs the lines between the sacred and the profane (Kozinets and Sherry 2004; Muñiz and Schau 2005; O'Guinn and Belk 1989) and spiritual practices, goods and festivities become de- and re-contextualized as they move across borders (Coskuner-Balli and Ertimur 2015; Ger and Belk 1996; Kimura and Belk 2005). Global consumption culture can revive and transform sacred practices by attaching them to new products and services (Sandikci and Ömeraki 2005). Yet, while we celebrate hybridization of belief through global-local encounters, we might, as Zigon (2007) suggests, actually be telling the story of how we think belief must be (rather than is) in different localities. The myths implied by our research move beyond being informative 'clues to the spiritual potentialities of the human life' (Campbell and Moyers 1991: 5) to skew our research on globalization.

A type of colonial, (auto)orientalizing gaze is inherent in this research as some consumer groups are allowed secular spirituality for divorcing ancient practices from their religious dogmas, while others remain in the sphere of the sacred and traditional. Studies in Western contexts have explored various modes of market-mediated secularized morality (e.g., consumer resistance, sustainability and green consumption, prosumption) and pursuit of enlightened spirituality in a global consumer culture. The reflexive consumer portrayed in these studies displays a future-orientation as she projects the global consequences of her consumption and she can turn away from a materialistic lifestyle in favor of a more spiritual one (Black and Cherrier 2010; Ekström 2015). For the non-Western 'others', religion is usually displayed as the main force that shapes the emerging markets (Mittelstaedt 2002) or the attention shifts from practices of consumers to policy-makers. In the former case, 'the other' has a rather limited and religion-based reflexivity to adopt or contest Western practices and moralities. The latter reveals the struggles of policy-makers to adapt Western sustainability guidelines and practices in their countries (Carrete et al. 2012; Ekström 2015) but fails to capture local forms of consumer reflexivity. Hence, local meanings and practices of sustainability for some consumer groups (see, for instance, Türe (2014) for a discussion of how Turkish consumers prevent waste by giving their disposable things to others), as well as local historical socio-economic contexts that nurture such differences, are lost to us (Ekström 2015). In either case, the myth that enlightened consumption practices, which are claimed to transcend the bounds of institutionalized religions, flow 'from West to East' is reinforced. This stance overlooks the argument (Grove 1990) that 'contemporary' ideologies of environmentalism might actually have originated from the early globalization cycles, as Western colonizers learned from the colonized 'others' new ways to relate to nature.

Another myth reinforced in global consumption research is that belief and morality translate as religion in most non-Western contexts. The popularity of research on halal consumption (Kamarulzaman et al. 2015) or Islamic brands (Izberk-Bilgin 2012) 
insinuates such an (internalized) dominant gaze. Researchers, with a Durkhemian stance that the moral is the social (Zigon 2007), also regard these societies through the lens of religious orientations dominant in their geographies. This conceals other types of moralities and socials (e.g., secular morality or non-religious spirituality) that are also prevalent in these contexts. In other words, focusing on religion, scholars tend to disregard alternative moralities and co-existing socials. Then, over-representation of religion as the major response to globalization in some parts of the world contributes to the myth of 'religiously extremist' peripheries against which the moral superiority of the Western centers is built. The ghost of neo-jihadism - Islam against global forces (Buck-Morss 2003; Friedman 2006; Huntington 1993) - ever-present in most research on Muslim consumers across the globe is a case in point.

Conversely, by treating religion-based consumption as a micro-level phenomenon in Western cultures, we might be missing the revival of religion as a global phenomenon (Thomas 2005). The recent rise of conservative ideologies and the popularity of fundamentalist politicians in Europe and the US affirm the conclusion O'Guinn and Belk (1989) reached 25 years ago. They pointed to the rise of The New Right: 'antielite, anti-intellectual, anti-big government, socially nostalgic, and [which] believes in material blessings for those who "love the lord and live right." ... The ideological label attached to the common foe is secular humanism' (p. 229). Such rare observations indicate (see also Ger 2013) that religion matters not just in 'developing' countries but also in 'developed' ones. That is, focusing too much on the differences of belief obscures the similarities across contexts. For instance, consumption patterns of a woman in a headscarf, beyond halal products or religious clothing, or how similar she can be to 'secular' women has not received much research attention. It also locks the consumption of some parties in the domain of enlightened spirituality and others solely in the domain of religion, making some moralities more visible or superior than others.

For researchers to really celebrate theoretical and methodological diversity and to understand the local consumers' experiences, it is crucial to be aware of the ideologies that contaminate their research. We have identified above some of the myths: the West is the center for non-religious forms of enlightened spirituality and reflexive morality; religion is the major domain through which 'the others' practice morality and unite against the global forces; and religious consumption is a micro-level phenomenon in Western contexts. These myths, in addition to reinforcing the dualities (e.g., East/Wiest, modern/Islamist) that we, consumer researchers, claim to demolish, prevent us from 'studying explicitly and analyzing local concepts of morality' (Zigon 2007, 131). Debunking these myths and adopting an inclusive view of belief in a global world require us to be open to diverse consumer experiences in different localities and look for similarities as well as differences. It requires resisting the temptation to use Western culture as reference - as 'the culture' (Waters 2001) - and to refrain from taking some moralities for granted in some contexts. We can, instead, try to bring in a broader critical view of globalization by tracing West-to-West or East-toEast global flows (see Tacey's (2013) study on how the Bateks in Malaysia negotiate the flow of Eastern and Western belief systems in their territory). This way, we can answer new questions such as 'how do global flows create different shades of belief in different localities?' or 'what are the counterparts of, for instance, infidel brands 
in the West or secularized moralities in the Middle East?' Producing and exploring such questions, in return, will help debunk the myths of morality and reflexivity in globalization research.

\section{QUESTIONING THE MYTH OF EMANCIPATORY POWER OF THE DIGITAL ON GLOBAL CULTURAL FLOWS}

Facilitated by digital networked technologies, the impact of globalization is now free from the constraints of temporal/spatial chasms. Connected through digital networks, global flows - of people, media, ideas, money, technology and things (Appadurai 1990) have seen an unprecedented acceleration and penetration into everyday consumption practices. But does this mean that now it is digitized globalization that mythically transforms Bauman's (2003) '[hu]man with no bonds' into human with no boundaries? Are consumers now in full control of what gets to flow across borders or are they only being offered a simulation of it? We think it is neither; yes, there are structural control mechanisms laid as traps that can lead consumers to just where the market wants them to be, yet if we can lay bare a roadmap of this digital world for consumers they can choose where they go and what to see.

Before the digitally connected world, global consumer culture flows were largely dictated through explicit knowledge retained, categorized and distributed by the more powerful agents in the global socio-economic system - dare we say the corporation? Then at the turn of the millennium, the world wide web started to be used in a transformative way - as a platform where knowledge is not only created and published by individuals but also modified and shared by networks of users in an open, participatory and collaborative fashion. Such knowledge is tacitly distributed among participants of a network where 'no one knows everything, everyone knows something, [and] all knowledge resides in humanity' (Levy 1997: 20). This is a socio-technological network, where human and non-human cultures interact based on varied agendas and infrastructures as they create and co-create meanings in the digitally connected world (Yenicioglu and Christodoulides 2013). Such borderless and participative interactions aim at expanding the experiences, knowledge and market power of participants and thus fundamentally disturb the established knowledge asymmetry democratizing the creation and sharing of the once dormant tacit knowledge. There are of course instances where the powers that be, freaking out about the loss of control they are faced with, erect borders in an attempt to limit such interactions. However, technologically savvy consumers not only find easy ways over, under, or around these borders, but also share such roadmaps with other network participants.

Consumers, as interpretive agents, may therefore gain this accolade once and for all within the global meaning-making system through this digital 'revolution'. Far from being the 'fragile flower that globalization tramples on' (Tomlinson 2003), consumers may now more than ever actively engage in the interplay of global cultural flows through socio-technological networks, continuously deterritorializing and reterritorializing the global village they live in, unifying global culture and generating diversity 
within it at the same time. As local everyday realities are continuously infiltrated by distant influences, perspectives and practices, global consumer culture becomes ever more rhizomic - a borderless plane of sameness in a constant flux.

Yet from a structural point of view, such a rhizome can be an architectural nightmare - 'a space that is equally impossible to live and to leave' (de Certeau 1997). Traditionally, local (such as the state) and global (such as the media and the brand) institutions negotiated socio-cultural policies that regulated individuals' interactions with global cultural flows. A panoptic architecture governs the level of cultural reflexivity of its always visible local inmates through an invisible (but always present) consumer culture ideal. The digitally networked socio-technological rhizome, on the other hand, is argued to be working with a different panoptic architecture. In the age of digital connectivity, it is not the threat of visibility, but rather the threat of invisibility that is designed to govern the interactions of participants (Bucher 2012). Power of agency in global cultural negotiations comes with an obligatory responsibility to be connected to the network. The number and level of interactions among human as well as non-human actors determine which cultural flows are going to be visible and hence important in negotiating local cultural meanings. Although digital global cultural flows seem to be in a constant flux with no apparent anchorage in a given local reality, there is an architectural structure to what is being visible and what is not for different participants of the socio-technological network. Facebook's Newsfeed for example is built according to an architectural algorithm which identifies the 'important' news items that are being shared within a network, 'relevant' to individual users. Such architectures are also dynamic and in a constant flux, changing shape as participants interact within the network. The panopticon requires actors to be visible and interact at all times in order to be in the know and also have a say in what others should know, or risk losing their agency in global cultural flows. Iqani and Schroeder (2015) call this constant penetration of the distant into the local, this global flow of digital interactions, hypervisibility.

Is this hypervisibility, this obligation to interact, this responsibility in selfreflection, and this urge to invite the distant in, just another form of spectacle dazzling the consumers with a false pretense of power and emancipation then? Or is it really moments of true participatory agency in constructing an interactive and evolving global consumer culture?

The digitally connected world neither offers a mythical emancipatory trapdoor for consumers nor does it magically hide in plain sight just another domination apparatus of the marketplace. It is for sure more powerful to be able to see the ordinary distant in all its glory and share one's own everyday realities with the world. The displacement of power to 'mediate', away from the usual suspects and towards individual actors, coupled with the growing importance of visibility, is opening up even the most private experiences of individuals to the public gaze as contributions to an evolving global culture (Lunt and Livingstone 2013).

But we should not underestimate the architecture of the digital panopticon and the underlying market realities that may more easily turn these participatory moments into commercially viable commodities for the profit of a few than the true negotiations of global cultural flows and local consumer identities. As technological systems semi-autonomously and ubiquitously permeate global cultural terrains, they may lose 
their ultimate objective (i.e., progressing quality of life) and instead turn into irrational and meaningless sign systems (e.g., the selfie). Fascinated and petrified at the same time by the spectacle, actors may come to accept the simulated culture (re)produced by hyperreal technological images as an immovable reality of life. Without an understanding of the consequences of global socio-technological interactions, individual agencies and creativity may develop into a perpetual reproduction of symbols of distinctions, divisions, and inequalities.

If we prefer global consumer culture to be signified in more than passively consumed commodities, in collectively transformed values, beliefs, and acts of its participants, unified for the improvement of global social welfare yet diversified to celebrate local realities, then our research needs to go beyond duly hailing or blaming digital networked technologies. Instead we need to expose their architecture and the consequences of that architecture for different actors such as the visible and the less visible or the bordered-out. We need to reflect on the participative opportunities and constraints offered by digital networked technologies and see beyond the veil of the sheer volume, variety, and velocity of global cultural flows therein.

\section{CONCLUSION: CALL FOR HISTORICAL AND CRITICAL REFLEXIVITY AND CROSS-DISCIPLINARITY FOR STUDIES OF GLOBAL CONSUMER CULTURES}

We have seen why what we call myths are myths and how easy and prevalent it is to fall prey to these myths that color our thinking as we study global consumption. Researchers tend to pay much more attention to positioning research questions and conceptualizations within ongoing debates in a particular (sub)discipline than considering what ideologies are being manifested in these very same research questions and concepts. While most scholars would acknowledge that our approaches and theories are themselves embedded in the neoliberal marketized world and its dominant ideologies, explicating and/or eliminating their manifestations and the consequences thereof have not been a widespread research practice. Thus, the obvious but difficult to exercise caveat is to be reflexive of latent ideologies at work in our scholarship; to consider how the political and academic milieu and its (sub)disciplinary scope shape the ways in which we think about globalization and consumption.

Like any other reflexivity exercise, researchers need to systematically consider their preferred interpretations and explanations, and their implications. If globalization is not a recent condition but a nonlinear process, then while developing conceptual models and arguments, researchers need to remind themselves of the underlying historical processes. We need to study consumption in dialogue with history studies and in relation to the historical processes of escalation and diminution of globalization - to its continuities and discontinuities.

If local-global encounters are not always playful but always laden with power relations, then while studying these encounters, researchers need to be aware of the history and politics of how a particular consumption object became an 'object of desire' in a foreign context, and which gaze this 'becoming' serves to validate. In other words, we 
need a cautious approach to the celebration of hybridity, so that we can unpack how privilege, inequality and domination - at the global scale - are reproduced through everyday acts and adventures.

Similarly, marketing and consumption researchers can uncover fresh ground if they study immigrant or 'local' or 'cosmopolitan' consumers as people with their specific social, religious, racial, ethnic positions and histories. Hence, moving beyond an acculturation lens and to a focus on the power struggle between the receiving and sending cultures and its manifestations in the immigrants' lives would enhance understanding of the interrelationships between immigration and markets/consumption in the global arena.

Correspondingly, if belief and morality have globally become references for solidifying socio-cultural divisions, then scholars must take care to question the taken-forgranted superiority of the center's moralities, and not to over-represent the import of religion or miss other shades of belief-morality in periphery contexts. In order to do so, we need to look for similarities as well as differences between and/or within our research contexts. Moreover, researchers need to be able to explore consumption and morality in different localities without necessarily using the West as the reference culture in interpreting observations.

Finally, if the volume, variety and velocity of digital networks draw a veil over the underlying market realities, in order to better understand the consequences of global digital connectivities, researchers would do well to study the underlying mechanisms and structures governing the distributed knowledge that is being generated by local participants all over the world. To understand the emancipatory possibilities as well as the barriers, we also need to investigate the divide between the visible and the invisible participants as well as the ways in which collaborative governance may work to weed out disinformation, manipulation and power games by the few.

Globalization amplifies awareness of a first (class) world and the experience of exclusion from it as well as social and economic polarization (de Koning 2009). Neoliberal policies widen global inequality and invite fundamental instability witness new social movements (Pieterse 2005). If global inequality is dire, if the exigency of boundaries, across classes and contexts is more common than ever (Pieterse 2001, 2005), Appadurai's widely cited flows 'have to be located in global and local histories of inequality and dominance' (de Koning 2009: 194). Flows involve symbolic translations across sites rather than mechanistic movement along inert passages (Rajagopal 2001). In these renditions, disjunctures in flows are used to the advantage of the powerful in global networks. Dominant 'global structures of common difference' (Wilk 1995) such as market institutions and their consumerist ideology define what types of diversity and hybrids will diffuse and what kinds will be curbed.

Similarly, if inequality and power struggles govern global markets and consumption, consumer culture studies (Arnould and Thompson 2005) and material culture studies (Miller 2008, 2010) have to also be located in global and local histories of dominance. Researchers need to attend to the embeddedness of consumer identity and practices or the materiality and objectification of social relations, respectively, within the historical and current socio/cultural/political relations between the North and South, the center and periphery, or the dominant and the dominated. 
Furthermore, the vulnerabilities as well as the complexities of globalization imply that disciplines need to speak to each other. These vulnerabilities include inequality (Pieterse 2005), ethnic/religious/national forms of violence (Friedman 2005), anti-globalization movements (Graeber 2005), and transnational criminal networks, business scandals and the commodification of human bodies (Comaroff and Comaroff 2005). Arguably, such liabilities are linked to the elevation of 'market imperatives ("the spirit of neoliberalism") to new heights where human dimensions are lost from view' (Edelman and Haugerud 2005: 158). In order to give voice to the human dimensions, as well as for a fundamental understanding of the phenomenon in the first place, researchers need to cross disciplinary boundaries and study global consumption from the perspective of social, moral/religious and political, as well as economic and cultural angles. Hence, we call for a willingness to engage with disciplines and perspectives other than our own - to cross the boundaries of thinking in theorization and research, as we study consumption across geographic boundaries. Arguably, studies of global consumption would benefit greatly from, particularly, subaltern studies, postcolonial studies, new social movements (including resistance to globalization) and human rights studies. Researchers of global consumer culture should confront the macro-processes and structures as well as the micro-structures and processes they tend to focus on. This has become more critical today, given the world political stage in 2017.

In sum, the prevalence of global dominance relations and the elevation of market imperatives call for both greater researcher reflexivity and deeper and sincere engagement with disciplines other than our own, whatever 'our own' might be. We, researchers, have a responsibility not to sanctify neocolonial and neoliberal might and boundaries. Instead we have a responsibility to try to avoid the myths and traps in our choice of topics to study, in deciding how to study them, and in developing conceptualizations and explanations. Such responsibility invites research interests in historicizing, domination and power struggles, the unabridged lives of consumers as people, with shades of moralities and similarities as well as differences of different local cultures, market structures and governance structures of digital networks.

\section{REFERENCES}

Ahmed, S., 2000. Strange Encounters: Embodied Others in Post-coloniality, Routledge, London and New York.

Altglas, V., 2014. From Yoga to Kabbalah: Religious Exoticism and the Logics of Bricolage, Oxford University Press, Oxford, UK.

Appadurai, A., 1990. Difference and disjuncture in the global cultural economy. Theory, Culture and Society, 7(2), 295-310.

Armitage, D., 2004. Is there a pre-history of globalization? In D. Cohen and M. O'Connor (eds), Comparison and History: Europe in Cross-National Perspective, pp. 165-176, Routledge, New York.

Arnould, E.J. and Thompson, C.J., 2005. Consumer culture theory (CCT): Twenty years of research. Journal of Consumer Research, 31(4), 868-882. 
Askegaard, S., Arnould, E.J. and Kjeldgaard, D., 2005. Postassimilationist ethnic consumer research: Qualifications and extensions. Journal of Consumer Research, $32(1), 160-170$.

Bauman, Z., 2003. Liquid Love, Polity Press, Cambridge.

Beck, U., 2000. What is Globalization? Polity Press, Cambridge.

Berry, J.W., 1980. Acculturation as varieties of adaptation. In Amado M. Padilla (ed.), Adaptation: Theory, Models and Some New Findings, pp. 9-26, American Association for the Advancement of Science, Washington, DC.

Beynon, J. and Dunkerley, D. (eds), 2000. Globalization: The Reader, Routledge, New York.

Bhabha, H.K., 1985a. Sly civility. October, 34, 71-80.

Bhabha, H.K., 1985b. Signs taken for wonders: Questions of ambivalence and authority under a tree outside Delhi, May 1817. Critical Inquiry, 12(1), 144-165.

Black, I.R. and Cherrier, H., 2010. Anti-consumption as part of living a sustainable lifestyle: Daily practices, contextual motivations and subjective values. Journal of Consumer Behaviour, 9(6), 437-453.

Bohman, A., 2015. It's who you know: Political influence on anti-immigrant attitudes and the moderating role of intergroup contact, Sociological Research Online, 20(3), Article number 6.

Bucher, T., 2012. Want to be on the top? Algorithmic power and the threat of invisibility on Facebook. New Media \& Society, 14(7), 1164-1180.

Buck-Morss, S., 2003. Thinking Past Terror: Islamism and Critical Theory on the Left, Verso, New York.

Burke, P., 2009. Cultural Hybridity, Polity Press, Cambridge.

Campbell, J. and Moyers, B., 1991. The Power of Myth, Anchor, New York.

Canniford, R. and Karababa, E., 2013. Partly primitive: Discursive constructions of the domestic surfer. Consumption Markets \& Culture, 16(2), 119-144.

Carrete, L., Castaño, R., Felix, R., Centeno, E. and González, E., 2012. Green consumer behavior in an emerging economy: Confusion, credibility, and compatibility. Journal of Consumer Marketing, 29(7), 470-481.

Clunas, C., 2004. Superfluous things: Material culture and social status in early modern China, University of Hawaii Press, Honolulu.

Comaroff, J. and Comaroff, J.L., 2005. Millennial capitalism and the culture of neoliberalism. In M. Edelman and A. Haugerud (eds), The Anthropology of Development and Globalization, pp. 177-188, Blackwell: Malden, MA.

Cook, I. and Harrison, M., 2003. Cross over food: Re-materializing postcolonial geographies. Transactions of the Institute of British Geographers, 28(3), 296-317.

Coskuner-Balli, G. and Ertimur, B., 2015. Creating hybridity: The case of American yoga. In K. Diehl and C. Yoon (eds), NA-Advances in Consumer Research, Vol. 43, 494-497, Association for Consumer Research, Duluth, MN.

de Certeau, M., 1997. The Capture of Speech and Other Political Writings, University of Minnesota Press, Minneapolis.

de Koning, A., 2009. Global Dreams: Space, Class, and Gender in Middle-Class Cairo, American University in Cairo Press, Cairo.

Dicken, P., 2007. Global Shift: Mapping the Changing Contours of the World Economy, Sage, London.

Edelman, M. and Haugerud, A. (eds) 2005. The Anthropology of Development and Globalization. Blackwell, Malden, MA.

Eisenstadt, S.N. and Schluchter, W., 1998. Introduction: Paths to early modernities: A comparative view. Daedalus, 127(3), 1-18. 
Ekström, K.M., 2015. Waste Management and Sustainable Consumption: Reflections on Consumer Waste, Routledge, London.

Fanon, F., 1967. Black Skin, White Masks. Pluto Press, London.

Featherstone, M., 1990. Global culture: An introduction. Theory, Culture \& Society, 7(2), $1-14$.

Febvre, L., 1977. Life in Renaissance France, Harvard University Press, Cambridge, MA.

Friedman, J., 2005. Globalization, dis-integration, re-organization: The transformations of violence. In M. Edelman and A. Haugerud (eds), The Anthropology of Development and Globalization, pp. 160-168, Blackwell, Malden, MA.

Friedman, T.L., 2006. The World is Flat: The Globalized World in the Twenty-first Century, Penguin, London.

Ger, G., 1999. Localizing in the global village: Local firms competing in global markets. California Management Review, 41(4), 64-83.

Ger, G., 2013. Islamic marketing at the nexus of global markets-religions-politics and implications for research. Marketing Theory, 13(4), 493-499.

Ger, G., 2017. Consumption in the web of local and global relations of dominance and belonging. In M. Keller, B. Halkier, T.A. Wilska and M. Truninger (eds), Routledge Handbook on Consumption, 121-134, Routledge, London.

Ger, G. and Belk, R.W., 1996. I'd like to buy the world a coke: Consumptionscapes of the 'less affluent world'. Journal of Consumer Policy, 19(3), 271-304.

Giddens, A., 1990. The Consequences of Modernity, Stanford University Press, Stanford, CA.

Graeber, D., 2005. The globalization movement: Some points of clarification. In M. Edelman, and A. Haugerud (eds), The Anthropology of Development and Globalization, 169-172, Blackwell, Malden, MA.

Grossberg, L., 1995. The space of culture, the power of space. In I. Chambers and L. Curti (eds), The postcolonial question: Common skies, divided horizons, pp. 169-188, Routledge, London.

Grove, R., 1990. The origins of environmentalism. Nature, 345(May), 11-14.

Hannerz, U., 1987. The world in creolisation. Africa, 57(04), 546-559.

Hannerz, U., 1992. Cultural Complexity: Studies in the Social Organization of Meaning, Columbia University Press, New York.

Hannerz, U., 1996. Transnational Connections, Routledge, London.

Heldke, L.M., 2001. Let's cook Thai: Recipes for colonialism. In S.A. Inness (ed.), Pilaf, Pozole, and Pad Thai: American Women and Ethnic Food, pp. 175-198, University of Massachusetts Press, Amherst, MA.

Heldke, L.M., 2003. Exotic Appetites: Ruminations of a Food Adventurer, Routledge, New York.

Holt, D.B., 1998. Does cultural capital structure American consumption? Journal of Consumer Research, 25(1), 1-25.

hooks, b., 1992. Black Looks: Race and Representation, South End Press, Boston.

Hopkins, A.G., 2002. The history of globalization - and the globalization of history? in A.G. Hopkins (ed.), Globalization in World History, pp. 11-46, Pimlico, London.

Huntington, S., 1993. The clash of civilizations? Foreign Affairs, 72(3), 22-50.

lan, C. and Michelle, H., 2003. Cross over food: Re-materializing postcolonial geographies. Transactions of the Institute of British Geographers, 28(3), 296-317.

Iqani, M. and Schroeder, J.E., 2015. \#selfie: Digital self-portraits as commodity form and consumption practice. Consumption Markets \& Culture, 19(5), 1-11.

Izberk-Bilgin, E., 2012. Infidel brands: Unveiling alternative meanings of global brands at the nexus of globalization, consumer culture, and Islamism. Journal of Consumer Research, 39(4), 663-687. 
Jaime-Castillo, A.M., Marqués-Perales, I. and Álvarez-Gálvez, J., 2016. 'The impact of social expenditure on attitudes towards immigration in Europe', Social Indicators Research, 126(3), 1089-1108.

James, H., 2009. The Creation and Destruction of Value: The Globalization Cycle, Harvard University Press, Cambridge, MA.

Kamarulzaman, Y., Veeck, A., Mumuni, A.G., Luqmani, M. and Quraeshi, Z.A., 2015. Religion, markets, and digital media seeking halal food in the US. Journal of Macromarketing, 36(4), 400-411.

Karababa, E., 2012. Investigating early modern Ottoman consumer culture in the light of Bursa probate inventories. The Economic History Review, 65(1), 194-219.

Karababa, E., 2015. Marketing and consuming flowers in the Ottoman Empire. Journal of Historical Research in Marketing, 7(2), 280-292.

Karababa, E. and Ger, G., 2011. Early modern Ottoman coffeehouse culture and the formation of the consumer subject. Journal of Consumer Research, 37(5), 737-760.

Kimura, J. and Belk, R.W., 2005. Christmas in Japan: Globalization versus localization. Consumption Markets \& Culture, 8(3), 325-338.

Kjeldgaard, D. and Ostberg, J., 2007. Coffee grounds and the global cup: Glocal consumer culture in Scandinavia. Consumption, Markets and Culture, 10(2), 175-187.

Kozinets, R.V., and Sherry Jr, J.F., 2004. Dancing on common ground: Exploring the sacred at Burning Man. In G. St. John (ed.), Rave Culture and Religion, pp. 287-303, Routledge, New York.

Kravets, O. and Sandikci, O., 2014. Competently ordinary: New middle class consumers in the emerging markets. Journal of Marketing, 78(4), 125-140.

Levitt, T., 1983. The globalization of markets. Harvard Business Review (May-June), 92-102.

Levy, P., 1997. Collective Intelligence, Plenum Trade, New York.

Liechty, M., 2002. Suitably Modern: Making Middle-class Culture in a New Consumer Society, Princeton University Press, Princeton, NJ.

Luedicke, M.K., 2011. Consumer acculturation theory: (Crossing) conceptual boundaries. Consumption Markets \& Culture, 14(3), 223-244.

Luedicke, M.K., 2015. Indigenes' responses to immigrants' consumer acculturation: A relational configuration analysis. Journal of Consumer Research, 42(1), 109-129.

Lunt, P. and Livingstone, S., 2013. Media studies' fascination with the concept of the public sphere: Critical reflections and emerging debates. Media, Culture \& Society, 35(1), 87-96.

Mears, A., 2010. Size zero high-end ethnic: Cultural production and the reproduction of culture in fashion modeling. Poetics, 38(1), 21-46.

Mierina, I. and Koroleva, I., 2015. Support for far right ideology and anti-immigrant attitudes among youth in Europe: A comparative analysis, Sociological Review, 63, 183-205.

Miller, D., 2008. The Comfort of Things. Polity: Cambridge.

Miller, D., 2010. Stuff. Cambridge: Polity.

Minowa, Y. and Witkowski, T.H., 2009. State promotion of consumerism in Safavid Iran: Shah Abbas I and royal silk textiles. Journal of Historical Research in Marketing, 1(2), 295-317.

Mittelstaedt, J.D., 2002. A framework for understanding the relationships between religions and markets. Journal of Macromarketing, 22(1), 6-18.

Muñiz, A.M. and Schau, H.J., 2005. Religiosity in the abandoned Apple Newton brand community. Journal of Consumer Research, 31(4), 737-747. 
Narayan, U., 1995. Eating cultures: Incorporation, identity and Indian food. Social Identities, 1(1), 63-86.

O'Guinn, T.C. and Belk, R.W., 1989. Heaven on earth: Consumption at Heritage Village, USA. Journal of Consumer Research, 16(2), 227-238.

Oswald, L.R., 1999. Culture swapping: Consumption and the ethnogenesis of middleclass Haitian immigrants. Journal of Consumer Research, 25(4), 303-318.

Oxford English Dictionary, http://www.oed.com/.

Peñaloza, L., 1994. Atravesando fronteras/border crossings: A critical ethnographic exploration of the consumer acculturation of Mexican immigrants. Journal of Consumer Research, 21(1), 32-54.

Pieterse, J.N., 1994. Globalisation as hybridisation. International Sociology, 9(2), 161-184.

Pieterse, J.N., 2001. Hybridity, so what? The anti-hybridity backlash and the riddles of recognition. Theory, Culture \& Society, 18(2-3), 219-245.

Pieterse, J.N., 2005. Global inequality: Bringing politics back in. In C. Calhoun, C. Rojek and B. Turner (eds), The SAGE Handbook of Sociology, 423-441, Sage, London.

Pieterse, J.N., 2009. Globalization and Culture: Global Mélange, Rowman and Littlefield Publishers, New York.

Pieterse, J.N., 2012. Periodizing globalization: Histories of globalization. New Global Studies, 6(2), 1-25.

Portes, A. and Zhou, M., 1993. 'Segmented assimilation and its variants', The Annals of the American Academy of Political Social Science, 530(November), 74-96.

Rajagopal, A., 2001. Politics after Television: Hindu Nationalism and the Reshaping of the Public in India, Cambridge: Cambridge University Press.

Ritzer, G., 1996. Sociological Theory, Tata McGraw-Hill Education, New York.

Ritzer, G., 2007. The Blackwell Companion to Globalization, Blackwell, Oxford.

Robertson, R., 1995. Glocalization: Time-space and homogeneity-heterogeneity. In M. Featherstone, S. Lash and R. Robertson (eds), Global Modernitjes, pp. 25-44, Sage, London.

Robertson, R. and White, K.E., 2005. Globalization: Sociology and cross-disciplinarity. In C. Calhoun, C. Rojek and B. Turner (eds), The Sage Handbook of Sociology, 345-366, Sage, London.

Root, D., 1996. Cannibal Culture: Art, Appropriation, and the Commodification of Diffierence, Westview Press, Boulder, CO.

Said, E., 1978. Orientalism, Vintage, New York.

Sandikci, Ö. and Ger, G., 2010. Veiling in style: How does a stigmatized practice become fashionable? Journal of Consumer Research, 37(1), 15-36.

Sandikci, Ö. and Ömeraki, S., 2005. Globalization and rituals: Does Ramadan turn into Christmas? NA-Advances in Consumer Research, 34, 610-615.

Shohat, E., 1992. Notes on the 'post-colonial'. Social Text, (31/32), 99-113.

Skrbiš, Z. and Woodward, I., 2013. Cosmopolitanism: Uses of the Idea, Sage, London.

Stearns, P.N., 2006. Consumerism in World History: The Global Transformation of Desire, Routledge, London.

Stearns, P.N., 2010. Globalization in World History, Routledge, London.

Stiglitz, J.E., 2002. Globalization and its Discontents, Penguin, London.

Tacey, I., 2013. Tropes of fear: The impact of globalization on Batek religious landscapes. Religions, 4(2), 240-266.

Thomas, S.M., 2005. The Global Resurgence of Religion and the Transformation of International Relations, Palgrave Macmillan, New York.

Tomlinson, J., 1999. Globalization and Culture, University of Chicago Press, Chicago. 
Tomlinson, J., 2003. Globalization and cultural identity. In A. McGrew and D. Held (eds), The Global Transformations Reader: An Introduction to the Globalization Debate, pp. 269-278, Polity Press, Cambridge.

Türe, M., 2014. Value-in-disposition: Exploring how consumers derive value from disposition of possessions. Marketing Theory, 14(1), 53-72.

Turgeon, L. and Pastinelli, M., 2002. 'Eat the world': Postcolonial encounters in Quebec City's ethnic restaurants. Journal of American Folklore, 115(456), 247-268.

United Nations Population Division, International Migration Report 2015, http://www. un.org/en/development/desa/population/migration/publications/migrationreport/docs/ MigrationReport2015.pdf

Üstüner, T. and Holt, D.B., 2007. Dominated consumer acculturation: The social construction of poor migrant women's consumer identity projects in a Turkish squatter neighbourhood. Journal of Consumer Research, 34(4), 41-56.

Üstüner, T. and Holt, D.B., 2010. Toward a theory of status consumption in less industrialized countries. Journal of Consumer Research, 37(1), 37-56.

Waters, M., 2001. Globalization, Routledge, London and New York.

Wilk, R., 1995. Learning to be local in Belize: Global systems of common difference. In D. Miller (ed.), Worlds Apart: Modernity through the Prism of the Local, pp. 110-133, Routledge, London.

Wilk, R., 1998. Emulation, imitation, and global consumerism. Organization \& Environment, 11(3), 314-333.

Wilk, R., 2006a. Home Cooking in the Global Village: Caribbean Food from Buccaneers to Ecotourists, Berg, Oxford.

Wilk, R., 2006b. Bottled water: The pure commodity in the age of branding. Journal of Consumer Culture, 6(3), 303-325.

Wilk, R., 2006c. Consumer culture and extractive industry on the margins of the world system. In J. Brewer and F. Trentmann (eds), Consumer Cultures: Global Perspectives, Berg, Oxford.

Wilk, R., 2010. Consumption in an age of globalization and localization. In K. Ekstrom and K. Glans (eds), Beyond the Consumption Bubble. Routledge Interpretive Marketing Research, New York.

Yenicioglu, B. and Christodoulides, G., 2013. Internet technologies and branding. In L. Moutinho, E. Bigne, and A.K. Manrai (eds), The Routledge Companion to the Future of Marketing, pp. 268-282, Routledge, London.

Zigon, J., 2007. Moral breakdown and the ethical demand: A theoretical framework for an anthropology of moralities. Anthropological Theory, 7(2), 131-150. 